The Effect of Competence Human Resources, Implementing Commitments, Implementation of Regulation and Quality of Training on Compliance with Government

Regulation Number 71 of 2010 Regarding Fixed Assets

\title{
The Effect of Competence Human Resources, Implementing Commitments, Implementation of Regulation and Quality of Training on Compliance with Government Regulation Number 71 of 2010 Regarding Fixed Assets
}

\author{
Dri Asmawanti ${ }^{1^{*}}$, Vika Fitranita ${ }^{2}$, and Ihsan Hanin Setiadji ${ }^{3}$ \\ 1,2,3 Universitas Bengkulu, Bengkulu, Indonesia
}

\begin{abstract}
This study aims to test and prove the influence of human resource competencies, implementing commitments, implementing regulations, and the quality of training on compliance with government regulation number 71 of 2010 regarding fixed assets. The population in this study were all financial management apparatus in the Regional Devices Organization in the City Government of Bengkulu. The data used in this study are primary data, which was obtained by distributing questionnaires to the respondents. The sample in this study amounted to 146 respondents, data analysis was performed using SPSS version 22. Hypothesis testing used multiple linear analysis. The results showed that the competence of human resources, implementing commitment, the application of regulations, and the quality of training proved to have a positive effect on compliance with government regulation number 71 of 2010 regarding fixed assets.
\end{abstract}

Keywords: Commitment, Competence, Compliance, Regulations, Training

\section{Introduction}

In the current reform era, there is a tendency for people to adopt local governments to implement good governance. Mardiasmo (2002) states that the first step that can be taken to realize good governance is the application of a fair, transparent, and accountable government accounting system. Government accounting in this case is used as a tool to make efforts to elaborate good governance to a more real level. To achieve this, one of the steps that need to be implemented is through accrual-based Government Accounting Standards (SAP). Manosoh (2015) states that overall accrualbased SAP is a manifestation of Good Government Governance which is used in the field of government finance as a form of resource management through a process that is accountable, transparent, accountable, and fair. Good Government Governance can also be defined as efficient public service, a reliable court system, and a government that is accountable to the public. In general, accounting recognizes two types of basis, namely cash basis (cash basis) and accrual basis (accrual basis). And in general also that the cash base has been abandoned, which then the manager of the accounting report has switched to the accrual basis. The accrual basis is not only applied to commercial accounting but is currently also being applied to the public sector, although in reality, it is still not optimal. There are still various opportunities and challenges that must be faced for the government to be transparent in financial management.

The use of proper accounting basis needs to be applied in government financial reports. This aims to produce good financial reporting. Accountable financial reporting is a form of accountability to the people, which in preparing financial reports is required to follow the matters contained in the current Government Accounting Standards (SAP). Current SAP states that the government needs to fully implement accrual-based SAP.

The Regional Government of Bengkulu City built an accounting basis following the Government Accounting Standards (SAP) through efforts to implement

* Corresponding author. Email address : dri_asmawanti@yahoo.com 
Government Regulation No. 71 of 2010. One of the efforts made by the Regional Government of Bengkulu City is through guidance in the field of increasing Human Resources by organizing a Technical Guidance program (BIMTEK) for the preparation of Accrual-Based Regional Government Financial Reports in 2014 the following year (2015) (bpkd.bengkuluprov.go.id). Technical Guidance participants include officials and staff within the Provincial Inspectorate, General Bureau, and Financial Management Bureau concurrently organizer. It aims to establish financial governance following what is stated in Government Regulation No. 71 of 2010 and Permendagri No. 64 of 2013.

In various regions in Indonesia, there have been many studies on the application of accrual-based accounting. The factors in previous research have various similarities with the examination of various factors examined in the BPK report regarding accurate results regarding the implementation of SAP implementation in Bengkulu City which include: Implementing commitment, regulations, and human resources. Overall, the results of the performance examination on the effectiveness of local government efforts in implementing accrual-based SAP in the Bengkulu City Government show that there are commitments, regulations, and policies; HR management of financial, asset, IT, and financial report reviewers; and the management of information technology related to accrual-based SAP implementation is still not effective (LHPK-BPK RI). Bengkulu City in the 2015 Fiscal Year failed to maintain the Unqualified (WTP) audit opinion so that in that fiscal year the City of Bengkulu only received the Unqualified Opinion (WDP). This is inseparable from problems that require attention from the internal control system, one of which is because the Bengkulu City government has not fully implemented the accrual-based Government Accounting Standards (bengkulu.bpk.go.id).

Various previous studies have reported on the application of accrual-based accounting in the public sector in Indonesia. This study is different from previous studies which both examined the application of Government Accounting Standards. This study aims to see the effect of human resource competence and quality of information on PP. Number 71 of 2010 related to fixed assets. Therefore, this study not only examines the application of Government Accounting Standards but this research will focus more on the fulfillment of Government Accounting Standards related to fixed assets.

The form of non-compliance deviations is following the Bengkulu Province BPK report. This is based on various factors that enable government officials to behave in compliance with provisions in SAP regarding fixed assets. These include the competence of human resources which is a combination of knowledge, skills, and abilities in doing their jobs. To achieve compliance in implementing SAP regarding the provisions of the fixed asset policy requires competent knowledge, skills, and abilities in their respective fields. Implementing commitments are also involved so that all provisions regarding SAP regarding fixed assets can always be obeyed. Implementing commitments into attitudes and behaviors that can encourage one another. Through the right commitment, the form of compliance in the implementation of SAP related to fixed assets can be fulfilled properly. The application of regulations is difficult to separate in carrying out various procedures. With the implementation regulation, it can serve as a guideline for related parties in carrying out their work, including in this case related to SAP's compliance with fixed assets. Training is equally important in having an impact on SAP compliance concerning fixed assets. This is because the quality of the training itself can improve the skills and knowledge of government officials. In this case, knowledge and skills are needed in carrying out various accounting procedures regarding SAP on fixed assets so that compliance can be realized.

Based on the description above, the researcher is interested in seeing the level of supervision of the Bengkulu City Government in regulating Government Regulation Number 71 of 2010 concerning fixed asset policy through analysis of actors in regional financial management. With the enactment of Government Regulation No. 71/2010, it 
The Effect of Competence Human Resources, Implementing Commitments, Implementation of Regulation and Quality of Training on Compliance with Government

Regulation Number 71 of 2010 Regarding Fixed Assets

is hoped that the realization of quality financial reporting can be accounted for so that good governance (good governance) in Indonesia can be realized.

\section{Literature Study/Hypotheses Development}

New Public Management (NPM) bermula dari teori manajemen yang beranggapan bahwa praktik bisnis komersial dan manajemen sektor swasta lebih baik dibandingkan dengan praktik dan manajemen pada sektor publik. Oleh karena itu, dalam rangka memerbaiki kinerja sektor publik, perlu diadopsi beberapa praktik dan teknik manajemen yang diterapkan di sektor swasta ke dalam sektor publik, seperti halnya pengadopsian mekanisme pasar, kompetisi tender, dan privatisasi perusahaanperusahaan publik (Mardiasmo, 2002).

Through changes in the public sector, there has also been a change in public sector accounting, namely a change in the accounting system from cash-based accounting to accrual-based accounting. This change is necessary because the current cash-based accounting system is no longer satisfactory, mainly because it lacks in presenting an accurate picture and in providing useful and adequate management information to facilitate the planning and performance process (Cohen \& Zorgios, 2007). According to Christiaens (2001) government accounting reform is the first step in government reform and an important condition as well as a precondition for confidence for other government reforms. Armaini (2017) conducted research related to the application of accrual-based accounting in the South Sumatra Provincial Government. The results showed that human resources and information technology simultaneously had a positive and significant effect on accrual-based accounting beliefs. HR and Information Technology variables partially have a significant positive effect on accrual-based accounting education.

Saputri (2016) conducted tests on education levels, financial training, information technology quality, and accrual-based organizational management. The population is Budget User Officials (PA) in OPD in Sidoarjo Regency Government. The results showed that the education level of financial employees, the quality of information technology, and organizational commitment had a positive effect on the application of accrual-based accounting in the Sidoarjo regency government. Meanwhile, financial training does not affect the application of accrual-based accounting. Surepno (2015) analyzes the success of the Semarang City Government in implementing accrual-based accounting. The object under study is the Regional Financial and Asset Management Office (DPKAD) Semarang City. The results showed that the success of the implementation of accrual-based accounting by the Semarang City Government was supported by leadership commitment, regulatory development, information system development, and human resource development. Furthermore, based on the conclusion of the implementers, it shows that accrual-based accounting has a strategic role in increasing transparency and accountability through financial reporting.

Sudaryati and Heriningsih (2014) examined the effect of human resource competence on the application of accrual accounting with supporting tools as a moderating variable in the scope of the Yogyakarta City Government. The population consists of the Head of OPD and PPK OPD staff in the regional government of Yogyakarta City. The results show that the competence of human resources has a significant effect on the success of accrual-based accounting. However, the competence of human resources related to supporting tools has no significant effect on the successful application of accrual-based accounting. Sugiarto and Alfian (2014) examine various factors that support the successful application of accrual-based accounting. The study population was employees of the Surakarta City Parks and Sanitation Department. The results showed that human resources, commitment, motivation, and culture partially influence the successful application of accrual-based accounting based on government accounting standards. Meanwhile, supporting tools do not affect the success of accrual-based accounting. Usman and Farida (2014) examined the level of accrual accounting implementation in local governments, 
especially at the work unit level with the population of the research object in the form of a Budget User Authority (KPA) from the Regional Apparatus Organization (OPD) of the Department of Industry, Trade, Cooperatives and UKM Ponorogo 2014. The results showed that the implementation of accrual accounting in government is still very low. Accrual accounting implementation is obtained significantly through training financial staff. However, there is no significant influence between the level of employee education, the quality of information technology consultants, support, experience, educational background, and work units on the level of accrual accounting implementation. Rahmansah (2012) researched the factors that influence the success of implementing PP. number 71 of 2010. The results of this study indicate that regulations, commitment, human resources, and supporting devices influence the successful implementation of PP. Number 71 of 2010 in the Provincial Government of Bangka Belitung Regency.

\section{The Effect of Human Resources Competence on PP Compliance. Number 71 of 2010 Related to Fixed Assets}

According to Wibowo (2007), human resource competence is competence related to knowledge, skills, abilities, and personality characteristics that directly affect performance. Competence can be seen from the educational background, training, and skills practiced in carrying out the task. Competence is a characteristic of someone who has the skills, knowledge, and ability to carry out a job (Hevesi 2005). Sudaryati and Heriningsih (2014) state that human resource competence has a significant effect on the success of accrual-based accounting. This is different from the results of testing regression model 2 in that human resources associated with supporting tools do not have a significant effect on the success of accrual-based accounting. Likewise, Armaini (2017) states that Human Resources have a positive and significant effect on the success of implementing accrual-based accounting.

Based on the description above, the hypothesis is formulated as follows:

$\mathrm{H}_{1}$ : Human resource competence has a positive effect on PP compliance. Number 71 of 2010 related to fixed assets.

\section{The Influence of Implementing Commitments on PP Compliance. Number 71 of 2010 Related to Fixed Assets}

Rahmansah (2012) states that simultaneously regulation, commitment, human resources, and supporting tools affect the successful implementation of Government Regulation Number 71 of 2010 concerning accrual-based Government Accounting Standards. Sugiarto and Alfian (2014) state that factors in the form of human resources, commitment, motivation, and culture are among the factors that influence the successful application of accrual-based accounting based on accrual-based Government Accounting Standards (SAP). Surepno (2015) also states that the Semarang City Government has the initiative to present financial reports as a private sector. Accrual-based accounting in Semarang was initiated by the mayor's desire that the resulting financial reports should resemble private-sector financial reports that can be used as a basis for decision making. The results and discussion show that management commitment is one of the main components to support the successful implementation of accrual-based accounting.

The role of the leader has a great influence on success. This is stated according to Bastian (2006) which states that strong support from leadership is the key to the success of a change. The weakness in the preparation of financial reports in several Ministries / Agencies is due to the weak commitment of the head of the work unit, especially the work unit, especially the Regional Work Unit (SKPD) who receives Deconcentration / Assistance Task funds. The success of implementation is also based on the compliance of a group. This was stated by Akib (2010) who stated that policy implementation is needed to see the compliance of the policy target group. Therefore, 
The Effect of Competence Human Resources, Implementing Commitments, Implementation of Regulation and Quality of Training on Compliance with Government

Regulation Number 71 of 2010 Regarding Fixed Assets

from a behavioral perspective, the compliance of target groups is an important factor determining the success of policy implementation. executive commitment is a form of attitude and behavior that encourages one another. This drive contributes to organizational values, psychological involvement, and loyalty, which in this case are manifested in the successful implementation of policies. This can occur because the related parties have promised their commitment in carrying out the stipulated provisions, among others, the provisions stated in PSAP 07 related to fixed assets.

Based on the description above, the hypothesis is formulated as follows:

$\mathrm{H}_{2}$ : Implementing commitment has a positive effect on PP compliance. Number 71 of 2010 related to fixed assets.

\section{The Effect of Regulation Application on PP Compliance. Number 71 of 2010 Related to Fixed Assets}

Public organizations need public regulation as a tool to streamline the public sector accounting cycle so that organizational goals are achieved (Bastian, 2010). According to Rahmansah (2012) states that regulation is positively influenced by the application of accrual accounting. Simultaneously, regulations, commitment, human resources, and supporting tools influence the successful implementation of PP. 71/2010 concerning Accrual-based Government Accounting Standards. In Surepno's research (2015) it was found that regulation is very important because regulations serve as guidelines for implementing actors to run a new system. The implementation of accrual accounting in the Semarang City Government has never been separated from the regulations prepared by the Accounting section of the DPKAD. This regulation is socialized to each SKPD to be applied in preparing financial reports. Regulation is a guideline for parties related to the implementation of a system. The government needs to develop regulations related to the system, in this case, the accrual-based Government Accounting Standards (SAP). It is necessary to adjust government regulations in each region to their relationship with PP. 71/2010 concerning Government Accounting Standards (SAP) accrual basis. The development of the regulation itself is expected to bring about good changes, especially for the success of the intended implementation. Successful implementation is also based on group compliance. This was stated by Akib (2010) who stated that policy implementation is needed to see the compliance of the policy target group. Based on the description above, the hypothesis is formulated as follows:

$\mathrm{H}_{3}$ : The application of regulations has a positive effect on PP compliance. Number 71 of 2010 related to fixed assets.

\section{Effect of Training Quality on PP Compliance. Number 71 of 2010 Related to Fixed Assets}

Surepno (2015) states in the results of his research that the application of accrual accounting requires human resources who understand accounting. However, not all staff have good accounting skills. This is one of the obstacles in implementing accrualbased SAP. Therefore, to overcome this problem, intensive training was held for all financial staff. Kusuma (2013) states that financial staff training has a positive and significant effect on the level of accrual accounting application. This shows in the work unit studied that the training provided on accrual-based accounting has a positive and significant effect on the level of accrual accounting application. The low level of accrual accounting application indicates that training related to the application of accrual accounting in work units in the KPPN Semarang I area is still inadequate.

Research by Stamatiadis, Eriotis, and Vasiliou (2009) shows that the training provided to financial staff has a positive and significant effect on the level of accrualbased accounting compliance. In particular, the study revealed that aspects of organizational and technical capacity to take action, such as consultant support, quality of existing IT, education level of accounting department staff, and level of specialized training, were important positive factors in explaining implementation scenarios. 
Bernardin \& Russell (1993) argues that training is an attempt to improve the performance of certain jobs that are their responsibility, or work related to their work. Training is more related to improving the skills of employees who have occupied a particular job or task so that it puts more emphasis on skills.

Based on the description above, the hypothesis is formulated as follows:

$\mathrm{H}_{4}$ : The quality of training has a positive effect on PP compliance. Number 71 of 2010 related to fixed assets.

\section{Research Methodology}

The type of research to be carried out is research using a quantitative approach. Quantitative research is research based on the positivism philosophy used in researching a specific population or sample, data collection using research instruments, quantitative/statistical data analysis, which aims to test predetermined hypotheses (Sugiyono, 2012). Population is the whole group of people, events, or things that the researcher wants to investigate, while the subgroup or part of the population is the sample (Sekaran, 2006). The population in this study were all financial management apparatus in the Regional Apparatus Organization of the Bengkulu City Government. The samples used as criteria in this study were the Head of the Finance Sub Division, the Finance Staff, and the Head of Regional Apparatus Organizations in the Regional Government of Bengkulu City who had sufficient experience in implementing Government Accounting Standards with the criteria of having attended training related to the application of PSAP 07 related to fixed assets. and have worked for at least 5 years. The data used in the research will be obtained through the distribution of questionnaires given to respondents. Respondents who are willing to fill out the questionnaire will be given a questionnaire in the form of a questionnaire containing the questions to be answered. The distribution of questionnaires was carried out by directing the subjects to be studied. The completed questionnaires will be collected and returned to the researcher.

\section{Method of Analysis}

This research will be analyzed using analysis tools in the form of SPSS 22.0 for windows. Descriptive statistics are statistics that serve to describe or provide an overview of the object under study through the sample or population as it is, without analyzing and making generally accepted conclusions (Sugiyono, 2016). The quality of the data generated based on the research instrument can be evaluated by testing the reliability and validity. The test is carried out to determine the consistency and accuracy of the data collected based on the use of instruments. The validity test is used to measure whether a questionnaire is valid or not. The questionnaire is said to be valid if the questions on the questionnaire can reveal something that will be measured by the questionnaire itself (Ghozali, 2013). Testing the validity of the research is to use the Confirmatory Factor Analysis (CFA) method. The level of correlation between variables whether or not factor analysis can be carried out is measured using the Kaiser Meyer Olkin Measure of Sampling Adequacy (KMO MSA) and Bartlett's Test of Sphericity. The KMO test whose value ranges from 0 to 1 questions the feasibility of factor analysis. A reliability test is a tool for measuring a questionnaire which is an indicator of a variable or construct (Ghozali, 2013). The reliability test was done through Croncbach's test. If Cronchbach's alpha> 0.70 means a reliable instrument (Ghozali, 2013).

\section{Classic Assumption Test}

According to Ghozali (2013), the normality test aims to determine whether each variable is normally distributed or not. A good regression model is to have normal data distribution and close to normal. The multicollinearity test aims to test the regression model regarding whether or not there is a correlation between independent (independent) variables. To approach it, this research uses the Variance Inflation Factor 
The Effect of Competence Human Resources, Implementing Commitments, Implementation of Regulation and Quality of Training on Compliance with Government Regulation Number 71 of 2010 Regarding Fixed Assets

(VIF). The heteroscedasticity test is to test whether in the regression model there is an inequality of variance from one residual observation to another.

\section{Hypothesis testing}

Hypothesis testing is performed by multiple linear regression analysis. The feasibility test of the model shows whether the regression equation model used has shown a model that is feasible (fit) to be used in hypothesis testing. Decision making in this test, namely by looking at the significant value. The coefficient of determination (R2) is used to measure the ability of the model to explain the dependent variable. The coefficient of determination (R2) is expressed as a percentage. According to Ghozali (2013), the t statistical test shows how far the influence of one explanatory or independent variable individually in explaining the variation of the dependent variable.

\section{RESULT}

\section{Description of Research Data}

The questionnaire in this study was given to the Head of the Regional Apparatus Organization, the head of the finance subdivision, and staff in the finance section of the Bengkulu City Regional Government in each Regional Apparatus Organization consisting of 39 OPDs. Questionnaires were returned according to the agreement or for two weeks after distributing the questionnaires.

The sample in this study amounted to 234 respondents, from the questionnaire distributed with a presentation of $100 \%$. 36 questionnaires did not return, namely 15.4\%. 198 questionnaires were received back by the researcher, namely $84.6 \%$. For questionnaires that cannot be processed by researchers, 52 questionnaires or $22.2 \%$, this is because there are respondents who do not provide an assessment of all statements in the questionnaire. While the rest, 146 questionnaires or $62.4 \%$ can be processed. The following are details about the questionnaires that have been sent and received as described in table 4.1 below:

Table 1 Research Sample Data

\begin{tabular}{lcc}
\hline \multirow{2}{*}{\multicolumn{1}{c}{ Information }} & \multicolumn{2}{c}{ Respondents } \\
\cline { 2 - 3 } & Total & Percentage \\
\hline Total questionnaires were distributed & 234 & $100 \%$ \\
\hline Number of questionnaires that were not returned & $(36)$ & $(15,4 \%)$ \\
\hline Number of returned questionnaires & 198 & $84,6 \%$ \\
\hline Unprocessed questionnaire & $(52)$ & $(22,2 \%)$ \\
\hline Processable questionnaire & 146 & $62,4 \%$ \\
\hline \multicolumn{2}{c}{ Source: Primary data processed } & 2019
\end{tabular}

Source: Primary data processed, 2019

\section{Hypothesis Testing Results}

Table 2 Results of Multiple Linear Regression Analysis t Statistics

\begin{tabular}{lcccc}
\hline \multicolumn{1}{c}{ Variable } & $\begin{array}{c}\text { Statistical } \\
\text { Coefficient }\end{array}$ & $\begin{array}{c}\text { Value } \\
\text { t }\end{array}$ & Sig. & $\begin{array}{c}\text { Hypothesis } \\
\text { Confirmation }\end{array}$ \\
\hline Human Resources Competence & 0,359 & 6,723 & 0,000 & accepted \\
\hline Implementing Commitment & 0,160 & 3,560 & 0,001 & accepted \\
\hline Application of Regulation & 0,317 & 5,057 & 0,000 & accepted \\
\hline Quality of Training & 0,215 & 3,577 & 0,000 & accepted \\
\hline R Square & 0,817 & & & \\
\hline Adj R Square & 0,811 & & \\
\hline F & 156,940 \\
\hline
\end{tabular}

Source: Primary data processed, 2019 


\section{Discussion}

\section{The Influence of Human Resources Competence on Compliance with PP. Number} 71 of 2010 related to Fixed Assets

Hypothesis test results indicate that resource competence has a positive effect on the application of accrual-based government standards. This result is under several previous studies. Armaini (2017) states that human resources have a positive and significant relationship or influence on the application of accrual-based accounting. Professional human resources who understand what they are doing are the most important part for the government to better implement accrual-based accounting. Human resources are expected to master the application of accounting based on Government Regulation Number 71 of 2010, through the application of applicable Government Regulations. To realize the success of reforms in the government sector, the competence of human resources possessed by the government itself is needed. Through the performance of government officials with a high level of competence, it will encourage success in government administration in implementing PP. Number 71 of 2010 in particular on the various policies and provisions that apply in PSAP 07 regarding fixed assets owned by the government.

\section{The Effect of Implementing Commitments on Compliance with PP. Number 71 of 2010 related to Fixed Assets}

Based on the results of testing the second hypothesis, it shows that executive commitment has a positive effect on PP compliance. Number 71 of 2010 is related to fixed assets, which means that the second hypothesis is accepted. This means that the higher the commitment of the executor, the compliance with the PP. Number 71 of 2010 related to fixed assets. On the other hand, the lower the executive commitment, the lower the compliance with PP. Number 71 of 2010 related to fixed assets.

Turgler (2007) defines commitment as employee acceptance of organizational values (identification), psychological involvement (psychological immersion), and loyalty (affection attachment). Commitment is an attitude and behavior that is mutually reinforcing (reinforce) between one another. According to Bastian (2006), strong support from leadership is the key to the success of a change. One of the causes of weakness in the preparation of Financial Statements in several Ministries / Institutions is a weak commitment from the leadership. Therefore, commitment is an important and influential matter for success, in this case, the success is realized through the implementation of government accounting which refers to the PP. Number 71 of 2010 in particular on the various policies and provisions that apply in PSAP 07 regarding fixed assets owned by the government.

\section{The Effect of Regulation Application on Compliance with PP. Number 71 of 2010 related to Fixed Assets}

The results of hypothesis testing indicate that the application of regulations has a positive effect on compliance with PP. Number 71 of 2010 related to fixed assets. In other words, the higher the application of regulations from government officials regarding fixed assets of the government, the higher the compliance with PP. Number 71 of 2010 relating to fixed assets. Vice versa, the lower the level of implementation of regulations regarding fixed assets within the scope of government, the lower the level of compliance with PP. Number 71 of 2010 related to these fixed assets.

In the concept of New Public Management (NPM), it is explained that without adequate and successful implementation, all benefits, objectives, and hopes of reform will be lost because the new accounting system will not be able to provide relevant and accurate managerial and financial information to support it. Therefore, it is necessary to implement regulations into a form of concrete action in following various guidelines for certain parties to implement and operate a system, including regarding accounting policies and systems. The application of regulations is indispensable to assist related parties in carrying out accounting policies and accounting systems. To carry out the 
The Effect of Competence Human Resources, Implementing Commitments, Implementation of Regulation and Quality of Training on Compliance with Government Regulation Number 71 of 2010 Regarding Fixed Assets

accounting policies stated in PSAP 07 regarding fixed assets, it is necessary to apply regulations that serve as guidelines for related parties.

\section{Effect of Training Quality on Compliance with PP. Number 71 of 2010 related to Fixed Assets}

The results of hypothesis testing indicate that the quality of training has a positive effect on compliance with PP. Number 71 of 2010 related to fixed assets. This means, the higher the quality of training, the higher the compliance with PPs. Number 71 of 2010 related to fixed assets. Vice versa, the lower the quality of training, the lower the compliance with PP. Number 71 of 2010 related to fixed assets. Under the transformation wave of the New Public Management (NPM), such as organizations with organizational and managerial reforms. The effective and successful adoption of important and effective accounting reforms and dominant in the application of the practice and success of New Public Management practices and techniques in public organizations. Therefore, the quality of training can provide developments in the field of reform in the public sector in the context of its implementation as well as following training in accounting.

The quality of training has benefits in improving individual abilities through efforts to improve operational skills in carrying out their jobs. By increasing the quality of training, it can also improve operational skills in carrying out work. This is closely related to how related parties comply with the various provisions and provisions in PSAP 07 regarding fixed assets. To comply with the various provisions which contain the policies stated in SAP, it is necessary to have qualified quality in individuals so that their operational capabilities can be used in carrying out their work.

\section{Conclusion}

Based on the research results that have been obtained, it can be concluded into several points as follows:

1. Competence in human resources has a positive effect on PP compliance. Number 71 of 2010 related to fixed assets. The higher the competency level of human resources, the higher the compliance of PP. Number 71 of 2010 related to fixed assets.

2. Implementing commitment has a positive effect on PP compliance. Number 71 of 2010 related to fixed assets. The higher the commitment of the executor who contributes to the implementation of the system, the higher the compliance of the PP. Number 71 of 2010 related to fixed assets.

3. The application of regulations has a positive effect on PP compliance. Number 71 of 2010 related to fixed assets. Therefore, the higher the application of regulations from government officials concerning government fixed assets, the higher the compliance of PP. Number 71 of 2010 relating to fixed assets.

4. The quality of training has a positive effect on PP compliance. Number 71 of 2010 related to fixed assets. So, the higher the quality of training from government officials regarding the management of government fixed assets, the higher the PP compliance. Number 71 of 2010 relating to fixed assets.

\section{Research Implication}

The implications of this research are stated as follows:

1. Practically, this research can be used as input for those who are responsible for the quality of performance of regional financial management officers in the OPD City of Bengkulu, namely the Regional Financial and Asset Management Agency (BPKAD) in improving compliance in implementation and reporting in the accounting sector., particularly regarding the policy on fixed assets in government. 
2. Theoretically, this research is expected to be a development in the field of academic science, namely its relation to the theory of New Public Management (NPM). The efficient and effective application of accounting reforms in the public sector plays an important and dominant role in the implementation and success of practices expected in the concept of New Public Management (NPM). Therefore, improvement in terms of human resource competence, executive commitment, implementation of regulations, and quality of training is needed to realize good governance, namely to increase compliance with PSAP 07 related to fixed assets.

\section{Research Limitations} follows:

There are several limitations to this study. The limitations of this study are as

1. Variables affecting PP compliance. Number 71 of 2010 regarding fixed assets in this study consists of human resource competence, executive commitment, implementation of regulations, and quality of training. Meanwhile, other variables influence the dependent variable. This is evidenced by the value of Adj. R-Square is $81 \%$ so that the remaining $19 \%$ is influenced by other variables not examined in this study.

2. Respondents in this study only consisted of the Head of Service, Head of Finance, and Financial Staff at each OPD in Bengkulu City. This allows certain officeholders who are also relevant to be sampled in this study, such as goods managers or SIMDA (Regional Management Information System) operators. That way, the research sample can be more representative so that it can provide accurate information about the population being studied.

\section{Suggestions}

Based on the order above, the suggestions that the author proposes to the parties involved in this study are as follows:

1. Adding research variables related to compliance with government regulations related to fixed assets, as stated in Yunita and Rofelawaty (2019) regarding performance expectation variables and other variables contained in Azhar (2019) in the form of organizational supporting variables. With that, it is expected that later it can provide a broader picture of other factors related to the dependent variable in this study.

2. Relevant research respondents such as goods administrators and SIMDA operators who are closely related to the main tasks and functions related to policies and management of fixed assets of local governments. That way, the research sample can be more representative as well as provide accurate information about the population in subsequent studies, namely financial management officials who work in local governments.

\section{References}

Alfian, M., \& Sugiarto, E. S. (2014). Faktor-Faktor Pendukung Atas Keberhasilan Penerapan Akuntansi Berbasis Akrual Pada Pemerintahan di Kota Solo. Journal Economics \& Business Research Festival, 3 (1), 1713-1726.

Akib, H. (2010). Implementasi Kebijakan: Apa, Mengapa, dan Bagaimana. Jurnal Administrasi Publik, 1(1) 1 - 11.

Azhar. (2019). Pengaruh Persepsi Dukungan Organisasi dan Kepuasan Kerja terhadap Organizational Citizenship Behavior (OCB) dengan Komitmen Organisasi sebagai variabel mediator. Jurnal Fakultas Ekonomi dan Bisnis Universitas Ahmad Dahlan, 16 (1), 36 - 46. 
The Effect of Competence Human Resources, Implementing Commitments, Implementation of Regulation and Quality of Training on Compliance with Government Regulation Number 71 of 2010 Regarding Fixed Assets

Armaini, R. (2017). Pengaruh Sumber Daya Manusia Dan Teknologi Informasi Terhadap Keberhasilan Penerapan Akuntansi Berbasis Akrual Pada Pemerintah Provinsi Sumatera Selatan. Jurnal ACSY Politeknik Sekayu, 6 (2), 71 - 86.

Bastian, I. (2006). Akuntansi Sektor Publik : Suatu Pengantar. Jakarta: PT. Erlangga.

Bastian, I. (2010). Akuntansi Sektor Publik Suatu Pengantar. Jakarta: PT. Erlangga.

Badan Pemeriksa Keuangan Perwakilan Provinsi Bengkulu. 2016. Lima Kabupaten/Kota peroleh WDP, satu WTP. http://bengkulu.bpk.go. id/?p=5442. 9 Februari 2018.

Badan Pemeriksa Keuangan Perwakilan Provinsi Bengkulu. (2017). LKPD Kota Bengkulu 2016-WDP. http://bengkulu.bpk.go.id/?p=6153. 9 Februari 2018.

Badan Pemeriksa Keuangan Republik Indonesia. (2016). Laporan Hasil Pemeriksaan atas Laporan Keuangan Kota Bengkulu Tahun 2016. Bengkulu: BPK Perwakilan Provinsi Bengkulu.

Badan Pemeriksa Keuangan Republik Indonesia. (2015). Laporan Hasil Pemeriksaan Kinerja Efektivitas Upaya Implementasi Standar Akuntansi Pemerintahan

Basis Akrual Pemerinta Kota Bengkulu Tahun 2015. Bengkulu: BPK Perwakilan Provinsi Bengkulu.

Badan Pengawasan Keuangan dan Pembangunan. 2015. Pengenalan Sistem Informasi Manajemen Daerah (SIMDA). http://www.bpkp.go.id/sakd/konten/333/Versi2.1.bpkp 11 April 2018.

Bernardin, H. J., \& Russel, E. A. (1993). Human resource Management, An Experiential Approach. Mc. Graw Hill International Edition. Singapore: Mac Graw Hill Book Co.

Biro Pengelola Keuangan Sekretariat Daerah Provinsi Bengkulu. (2014). Bimbingan Teknis Penyusunan LKPD Berbasis Akrual. http://bpkd. bengkuluprov.go.id/index.php/80berita/100-bimbingan-teknis-penyusunan-lkpdberbasis-akrual. 5 Oktober 2017.

Biro Pengelola Keuangan Sekretariat Daerah Provinsi Bengkulu. (2015). Bimbingan Teknis Penyusunan LKPD Pemerintah Daerah Berbasis Akrual. http://bpkd.bengkuluprov.go.id/index.php/80-berita/102-bimbingan-teknispenyusunan-lkpd-pemerintah-daerah-berbasis-akrual. 5 Oktober 2017.

Christiaens, J. (2001). Converging New Public Management Reforms and Diverging Accounting Practices in Flemish Local Governments. Financial Accountability \& Management, 17 (2), 70 - 153.

Cohen, S. E. K., \& Zorgios, Y. (2007). Assessing IT as a Key Success Factor for Accrual Accounting Implementation in Greek Municipalities. Financial Accountability \& Management, 23 (1), 91-111.

Ghozali, I. (2013). Aplikasi Analisis Multivariate Dengan Program IBM SPSS. Semarang: Badan Penerbit Universitas Diponegoro.

Hevesi, G. A. (2005). Standards for Internal Control in New York State Government. www.osc.state.ny.us. Diakses tanggal 14 April 2018.

Kusuma, M. I., \& Yudha. (2013). Analisis Faktor- Faktor yang Mempengaruhi Tingkat Penerapan Akuntansi Akrual pada Pemerintah. Diponegoro Journal of Accounting, 2 (3), 1 - 14. 
Manosoh, H. (2015). Implementasi Sistem Akuntansi Pemerintahan Dalam Mewujudkan Good Government Governance Pada Pemerintah Provinsi Sulawesi Utara. Jurnal Berkala Ilmiah Efisiensi, 15 (5), 667 - 776.

Mardiasmo. (2002). Elaborasi Reformasi Akuntansi Sektor Publik: Telaah Kritis Terhadap Upaya Aktualisasi Kebutuhan System Akuntansi Keuangan Pemerintah Daerah. Jurnal Akunting Dan Auditing. Jurnal Akunting dan Auditing, 6 (1), 63 82.

Pemerintah Republik Indonesia. (2010). Peraturan Pemerintah No. 71 Tahun 2010 Tentang Standar Akuntansi Pemerintahan (Berbasis Akrual).

Rahmansah. (2012). Faktor- Faktor Yang mempengaruhi Keberhasilan Penerapan Peraturan Pemerintah Nomor 71 Tahun 2010 Pada Pemerintah Provinsi Kepulauan Bangka Belitung. Tesis tidak diterbitkan. Jakarta. Program Pascasarjana Universitas Terbuka Jakarta.

Saputri, S. K. (2016). Pengaruh Tingkat Pendidikan, Pelatihan Keuangan, Kualitas Teknologi Informasi, Serta Komitmen Organisasi Terhadap Penerapan Akuntansi Akrual di Pemerintah Kabupaten Sidoarjo (studi Persepsi). Tesis tidak diterbitkan. Surabaya. Program Pasca Sarjana Universitas Airlangga Surabaya.

Sekaran, U. (2006). Metodologi Penelitian untuk Bisnis. Buku 2. Edisi Pertama. Jakarta: Salemba Empat.

Stamatiadis, F., Eriotis, N., Vasiliou, V. (2009). Assessing Accrual Accounting Reform in Greek Public Hospitals: An Empirical Investigation. International Journal of Economic Science and Applied Research, 4 (1), 153-184.

Sudaryati, D., \& Heriningsih, S. (2014). Pengaruh Kompetensi Sumber Daya Manusia Terhadap Penerapan Akuntansi Akrual Dengan Perangkat Pendukung Sebagai Variabel Moderating (Studi Empiris Pada Pemerintah Kota Yogyakarta). UPN Veteren Yogyakarta.

Sugiyono. (2012). Metode Penelitian Administrasi. Cetakan ke-20. Bandung: Alfabeta.

Sugiyono. (2016). Statistik untuk Penelitian. Bandung: CV Alfabeta.

Surepno. (2015). Kunci Sukses dan Peran Strategis Implementasi Akuntansi Berbasis Akrual. Jurnal Dinamika Akuntansi, 7 (2), 119 - 128.

Turgler, B. (2007). Tax Compliance and Tax Morale. Cheltenham: Edward Elgar Publishing Ltd.

Usman, S., \& Farida, I. (2014). Analisis Faktor-Faktor Yang Mempengaruhi Implementasi Akuntansi Akrual pada Entitas Pemerintah Daerah. Jurnal Akuntansi dan Investasi, 15 (2), 101-113.

Wibowo. (2007). Manajemen Kinerja. Jakarta: PT. Raja Grafindo Persada.

Yunita., \& Rofelawaty. (2019). Analisis Pengaruh Ekspektasi Kinerja, Ekspektasi Usaha, Faktor Sosial dan Kondisi yang Memfasilitasi Terhadap Penggunaan Sistem Informasi Akuntansi. Jurnal Manajemen dan Akuntansi, 19 (2), 73 - 82 